\title{
China's Real Exchange Rate Puzzle
}

\author{
Rod Tyers \\ Australian National University \\ Jane Golley \\ Australian National University
}

\begin{abstract}
International pressure to revalue China's currency stems in part from the expectation that rapid economic growth should be associated with a real exchange rate appreciation. This hinges on the Balassa-Samuelson hypothesis under which economic growth is due to relative tradable productivity gains which cause rising relative non-traded prices. The puzzle is that, while evidence on China's productivity and prices supports this hypothesis, its real exchange rate showed no tendency to appreciate during 1990-2006. Resolution requires allowance for failures of the law of one price for traded goods, which expands the array of determinants to include labour supply growth and demand switches due to changes in investment interest premia, saving rates and trade distortions. The sensitivity of China's real exchange rate to these determinants is reviewed with the results confirming that financial outflows have been prominent depreciating forces since 1997. These, along with WTO accession trade reforms, have more than offset the Balassa-Samuelson productivity effects.
\end{abstract}

- JEL classification: C68, C53, E27, F21, F43, F47, O11

- Key words: Chinese economy, real exchange rate, economic growth, productivity

\footnotetext{
*Corresponding address: Professor Rod Tyers, School of Economics, College of Business and Economics, Australian National University, rod.tyers@anu.edu.au

(2008-Center for International Economics, Sejong Institution, All Rights Reserved.
} 


\section{Introduction}

It has been argued that the appreciation of the RMB since 2005 is just the beginning of a necessary upward trend, given the belief that the currency is currently undervalued, by margins ranging from 'small' to as high as $50 \%{ }^{1}$ Such expectations commonly depend on the Balassa (1964)-Samuelson (1964) hypothesis that implies a positive relationship between economic growth and the real exchange rate, driven by productivity catch-up in developing countries' tradable sectors and, in association, rising prices in their non-traded sectors. Two suppositions are essential to the hypothesis. First, relative to foreign trading partners, productivity rises fastest in the traded goods sector and, second, due to associated wage pressure, there is relative inflation of non-traded service prices.

This paper offers evidence in support of these suppositions in the case of China, lending additional weight to the expectation that the real exchange rate should be appreciating. At the same time, however, it shows that there has been no significant long term appreciating trend from the early 1990s through 2006. Therein lays the puzzle. Its resolution requires the generalisation of the assumptions on which the Balassa-Samuelson hypothesis is based; in particular, the relaxation of the assumption that the law of one price applies for all traded goods. This generalisation greatly broadens the set of determinants of the real exchange rate and it is to these that the paper then turns. It emerges that, while productivity changes are influential in the medium to long run, so also are labour force growth and trade reforms. In the short run movements in the real exchange rate prove to be dominated by the investment-saving balance and hence financial flows on the balance of payments. In the medium to long run the net effect of China's rapid economic growth on its real exchange rate depends on the sources of that growth and the consequent pattern of endowment changes and sectoral distributions of productivity growth and tradability. Yet, of most importance in resolving the puzzle is the rise of China's saving rate and its WTO accession trade policy reforms.

The next section briefly reviews the Balassa-Samuelson hypothesis and the evidence in support of its key suppositions, and then demonstrates its apparent inconsistency with the trend of China's real exchange rate. A more general treatment of real exchange rate determination is then offered in Section 3 and elasticities to various determinants are calculated using a simulation model of the global economy

${ }^{1}$ See, for example, Frankel (2004), Wang (2004), Goldstein (2004), Coudert and Couharde (2005) and Tyers et al. (2007). 
in Section 4. A final resolution of the puzzle is suggested in Section 5 and a discussion of the implications for Chinese macroeconomic policy is then provided in Section 6. General conclusions and policy implications are presented in Section 7.

\section{Balassa-Samuelson: Theory and Evidence for China}

If the nominal exchange rate, $E$, is defined as the number of units of foreign exchange obtained for a unit of the domestic currency, the real exchange rate, $e^{R}$, can be defined correspondingly as the rate of exchange between the home product bundle and corresponding bundles produced abroad. It follows that the bilateral real exchange rate for a focus (home) country with foreign trading partner $i$ can be approximated as the common currency ratio of the gross domestic product (GDP) prices (deflators) of the two countries, $P^{Y}\left(p^{N}, p^{T}\right)$ and $P_{i}^{Y}\left(p_{i}^{N}, p_{i}^{T}\right) / E_{i}$, where $p^{T}$ and $p^{N}$ are indices over all the focus country's non-traded and traded goods and services, respectively. ${ }^{2}$

$$
e_{i}^{R}=\frac{P^{Y}\left(p^{N}, p^{T}\right)}{P_{i}^{Y}\left(p_{i}^{N}, p_{i}^{T}\right) / E_{i}}=E_{i} \frac{P^{Y}\left(p^{N}, p^{T}\right)}{P_{i}^{Y}\left(p_{i}^{N}, p_{i}^{T}\right)}
$$

This is the fundamental relationship between the real and nominal exchange rates. Consider the case in which prices at home and abroad are measured relative to a common global numeraire, the share of non-traded products in GDP, $\theta$, is the same at home and abroad, prices are aggregated using a Cobb-Douglas index and the law of one price applies to all traded goods. The latter implies that trade is costless and undistorted, so that $p^{T}=p_{i}^{T}$. Under these conditions, the real exchange rate becomes

$$
e_{R}=\frac{\left(p^{N}\right)^{\theta}\left(p^{T}\right)^{1-\theta}}{\left(p_{i}^{N}\right)^{\theta}\left(p_{i}^{T}\right)^{1-\theta}}=\left(\frac{p^{N}}{p_{i}^{N}}\right)^{\theta}
$$

From this, the key role of non-traded goods prices is clear. When prices are measured in a common currency, or relative to a common numeraire, it is the ratio of the home and foreign non-traded goods prices that matters in determining the real exchange rate.

To illustrate the associated dependence on productivity, imagine that labour is

${ }^{2}$ Here we imagine that, rather than the continuum of tradability that is observed across goods and services, traded and non-traded goods are separated starkly as $T, N$. 
the single fixed factor and that the rates of output per worker in the home traded and non-traded sectors are $A^{T}$ and $A^{N}$. In trading partner $i$, the corresponding rates are $A_{i}{ }^{T}$ and $A_{i}{ }^{N}$. The relationships between the wage rate and product prices in the traded and non-traded sectors follow from equating the wage in both sectors with the values of the marginal products of labour in each: $W=A^{T} P^{T}=A^{N} P^{N}, W_{i}=A_{i}{ }^{T} P_{i}^{T}$ $=A_{i}^{N} P_{i}^{N}$, from which it follows that the divergence in wage rates between trading partners depends only on their tradable productivities: $W / W_{i}=A^{T} / A_{i}{ }^{T}$.

If the non-traded productivity level is the same in all trading partners $\left(A^{N}=A_{i}^{N} \forall i\right)$, we then have that

$$
\frac{P^{N}}{P_{i}^{N}}=\frac{A^{T}}{A_{i}^{T}}=\frac{W}{W_{i}} \text { and } e_{i}^{R}=\left(\frac{p^{N}}{p_{i}^{N}}\right)^{\theta}=\left(\frac{A^{T}}{A_{i}^{T}}\right)^{\theta}=\left(\frac{W}{W_{i}}\right)^{\theta} .
$$

Under the assumptions of the Balassa-Samuelson hypothesis, then, an economy that is growing faster than its trading partners also has 1) faster tradable productivity growth $\left.\left(\hat{A}^{T}>\hat{A}_{i}^{T}\right), 2\right)$ faster wage growth $\left.\left(\hat{W}>\hat{W}_{i}\right), 3\right)$ relative service price inflation $\left(\hat{p}^{N}>\hat{p}_{i}^{N}\right)$, and 4$)$ an appreciating real exchange rate $\left(\hat{e}_{R}>0\right)$. The hypothesis then implies that, if developing countries are poorer because their tradable labour productivity is lower, then their comparatively rapid growth should be associated with real appreciations against their richer trading partners.

\section{A. The Supporting Evidence for China}

The two key suppositions that are essential to the hypothesis are, first, that, productivity rises fastest in the traded goods sector and, second, due to associated wage pressure, that there is relative inflation of non-traded service prices. We examine these by estimating simple Solow residuals for the economy as a whole and for three sectors: 'Agriculture', 'Industry' and 'Services'. In doing so, we adjust the officially published urban employment data for underestimation, as discussed in Cai and Wang (2006). ${ }^{3}$ The average annual changes in the Solow residuals for each sector that emerge from this analysis are given in Table 1. These show strong productivity performance by the Chinese economy since the mid 1980s, with a slow-down in the 1998-2001 period associated with the East Asian financial crisis. Consistent with the first supposition, and with other studies by Lu (2006) and Fogel (2006), productivity growth appears to have been strongest in the export

\footnotetext{
${ }^{3}$ The 'Agriculture' sector is defined as Primary Industry plus Food Processing; 'Industry' as Secondary Industry minus Construction and Food Processing; while 'Services' is defined as Tertiary Industry plus Construction. See Tyers et al. (2006) for further details.
} 
Table 1. Estimated Chinese Total Factor Productivity Growth by Sector

\begin{tabular}{ccccc}
\hline \% per year & Whole economy & Agriculture & Industry & Services \\
\hline $1986-1989$ & 3.5 & 1.4 & 3.8 & 3.8 \\
$1990-1994$ & 5.0 & 1.6 & 7.7 & 2.3 \\
$1995-1997$ & 5.7 & 5.5 & 3.7 & 3.2 \\
$1998-2001$ & 4.1 & -0.2 & 8.9 & -0.5 \\
$2002-2005$ & 6.0 & 5.4 & 6.3 & 4.6 \\
\hline
\end{tabular}

Sources: Analysis of Chinese statistics described in Tyers et al. (2006). Original sources are, for output, China Statistical Year Book (2005), China Industrial Economic Statistical Year Book (every year after 1985) and China Statistical Abstract (2006). Employment data are from China Statistical Year Book (2005), China Industrial Economic Statistical Year Book (every year after 1985) and China Labor Statistical Year Book (every year after 1985). China's capital stock, in 2000 prices, is taken from Holtz (2006). Sectoral price indices are from China Statistical Abstract (2006). Urban employment is enlarged based on underestimation proportions from Cai and Wang (2006).

orientated industrial sector and weakest in the largely non-traded service sector. ${ }^{4}$

The second supposition is also supported by the evidence, as shown in Figure 1. The prices of construction and other services have clearly risen faster than the GDP price since 1990. On the (accurate) presumption that China's productivity growth is higher than that of its trading partners, this strongly supports a simultaneous real appreciation. Yet, as shown in Figure 2, when Chinese and US GDP prices are compared over the period 1990-2006 no such appreciating trend is observed. When, instead, we compare more frequently published producer prices to obtain a more recent view of the trend in the bilateral real exchange rate the result is shown in Figure 3. The ratio of these price indices is not a precise measure of the real exchange rate since the two indices have slightly different coverage, so the trend shown in the figure does not match that of Figure 2. Indeed it falls following the mid-1990s, reflecting China's deflation in this period. The change in China's nominal rate regime is also made clear in this figure. If anything, this evidence

${ }^{4}$ Services output volumes and prices are measured more poorly than those in merchandise sectors in all countries. These comparative measures therefore carry large error margins. Lu (2006) estimates labour productivity in China's manufacturing and service sectors between 1978 and 2004. He describes the evolution of China's manufacturing labour productivity after 1978 as a two-stage process: during the first stage (1978-90) it was only 1.9 per cent per annum, compared with a per capita GDP growth rate of 7.5 per cent; while during the second stage (1991-2004) it increased dramatically, averaging 13.1 per centsignificantly higher than the official per capita GDP growth rate of 8.2 per cent. Labour productivity in the service sector averaged 4.3 per cent per annum for the entire period. Fogel (2006) disaggregates per capita income growth between 1978 and 2002 and shows that 69 per cent of growth was due to increases in labour productivity, which grew most rapidly in industry (6.2 per cent per annum), nearly as high in agriculture (5.7 per cent) and lowest, but still substantial, in services (4.5 per cent). 
Figure 1. Chinese Sectoral Price Indices, 1995-2005

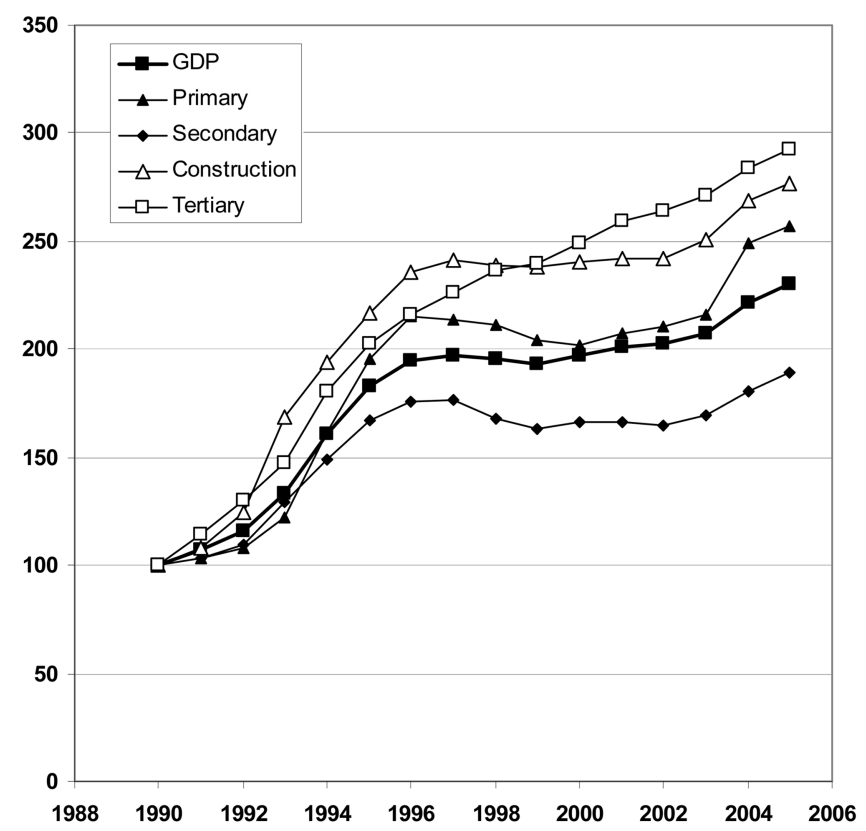

a: These are sectoral price indices for 'Primary industry', which is mainly agriculture; 'secondary industry', which is primarily manufacturing and construction; and 'tertiary industry', which is other services.

Source: The price indices are implied by volume and value data from the National Bureau of Statistics of China (2007).

Figure 2. Mainland China's Real Exchange Rate against the US since 1990a

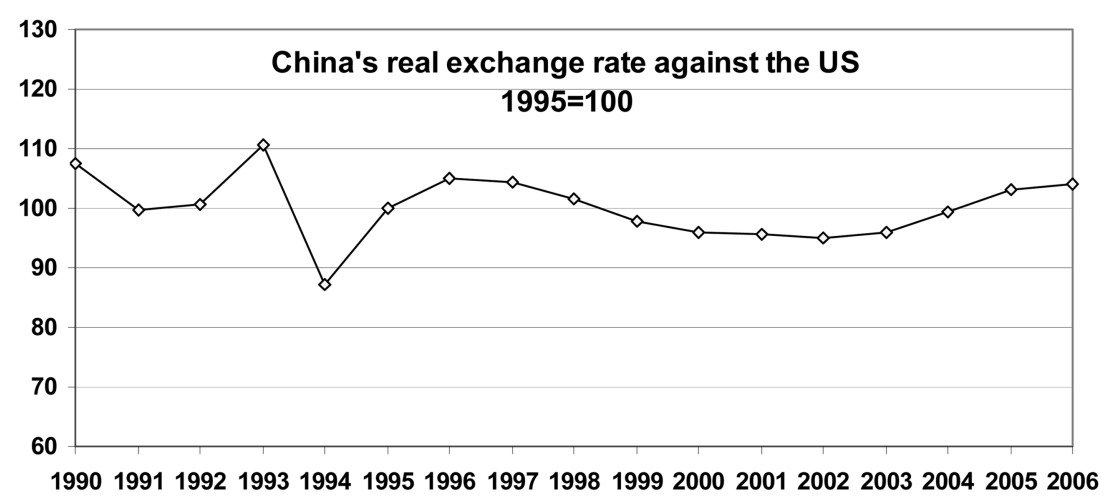

a: These are indices of nominal bilateral rates between mainland China and the US, deflated according to $e_{R}=E \cdot P_{Y} / P_{Y}^{U S}$, where $E$ is the nominal exchange rate in US\$ per unit of local currency, $P_{Y}$ is the local GDP price and $P_{Y}{ }^{U S}$ is the corresponding US GDP price.

Source: IMF, International Financial Statistics (2007). 
Figure 3. The Mainland China - US real Exchange Rate since 1995 on Producer Prices ${ }^{\mathrm{a}}$

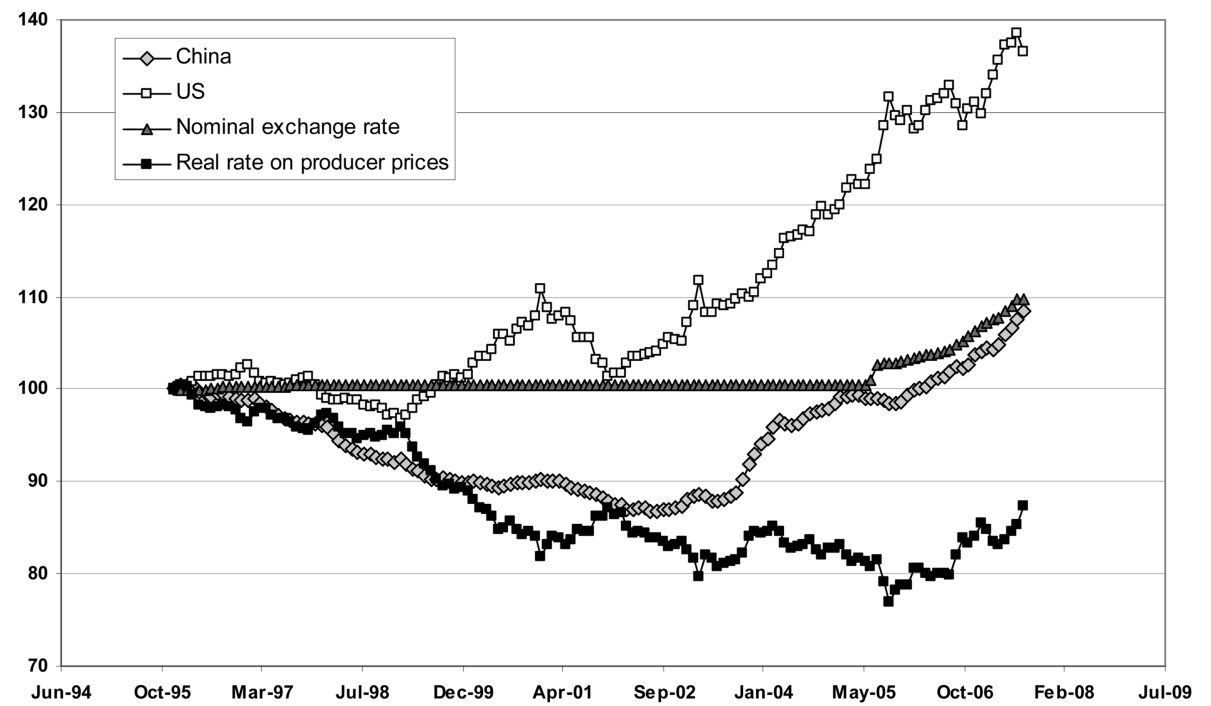

a: Here the home prices are, for the US, the Producer Price Index and, for China, the Corporate Goods Price Index. The Chinese index has more coverage of commodities and services, so this is a less than perfect comparison. The implied real exchange rate is in black.

Sources: IMF, International Financial Statistics (2007), National Bureau of Statistics of China (2007).

shows a depreciating trend since 1995 , contrary to the Balassa-Samuelson evidence. ${ }^{5}$ It is this puzzle that we seek to resolve. We begin with a generalisation of the hypothesis via a relaxation of some of its key assumptions.

\section{A Generalisation}

The key assumptions of the Balassa-Samuelson hypothesis are indeed suspect. We offer a critique of each, as follows.

Tradable productivity gap: During some periods and in some developing countries, productivity growth has been observed to be higher in the non-tradable sector, ${ }^{6}$ leading to $\hat{A}^{N}>\hat{A}_{i}^{N}$ and tending to depreciate the real exchange rate. Modern transport, financial, health and education services offer considerable potential for productivity catch-up. Whatever the relative performance of China's

${ }^{5}$ The turn up since 2005 shown in Figure 3 is significant as the determinant of recent inflationary pressure in China.

${ }^{6}$ For example, the Cold War infrastructure investments in Korea and Taiwan reduced service costs at early stages in their periods of rapid expansion. 
services sector in the past, recent evidence suggests substantial potential for catchup and accelerated productivity growth in the future (Ma 2006).

The law of one price for tradable goods: Failures of the law of one price have been observed for tradable goods in specific instances. ${ }^{7}$ That it fails particularly in the trade between China and the US is clear from the analysis by Amiti and Freund (2007). Goods and services are not homogeneous across countries but are differentiated at minimum by country of origin. ${ }^{8}$ Supply and/or demand side factors that raise the volume of tradable production move the home country down the global demand curves for its product varieties, reducing its supply prices and resulting in deterioration in the terms of trade and a depreciation of its real exchange rate. Factor endowment growth and changes in policy that lead to substitution in demand for home products depreciate real exchange rates and the magnitudes of their effects depend crucially on the degree of substitutability between the differentiated products.

Labour arbitrage: In most developing economies, the marginal product of industrial labour exceeds that of rural labour due to the more rapid accumulation of industrial capital. There is, therefore, a Harris-Todaro gulf between wages in the expanding and contracting sectors. Yet the key Balassa-Samuelson assumption is that the same wage is paid in the traded and non-traded sectors, principally the manufacturing and the services sectors. This assumption could fail if labour mobility between the rural and industrial sectors is inferior to that between the rural and service sectors (particularly construction). Were this the case, industrial productivity growth would drive up the industrial wage but the services wage need not rise to the same extent and this would moderate relative service price increases and hence real appreciations. Evidence for this difference in mobility is offered by Chang and Tyers (2003).

Closed capital account: The assumption that the real exchange rate depends only on interactions among countries associated with trade in merchandise is clearly violated in many of today's developing countries, and particularly in China. Its violation, in concert with failures of the law of one price for traded goods, means that any influx of payments (in the form of a foreign direct investment or portfolio capital flow) raises aggregate demand. Since traded goods are supplied

${ }^{7}$ See, for example, Bergin et al. (2006); Crucini et al. (2005); and Drine and Rault (2005).

${ }^{8}$ This is a standard assumption in the most widely used numerical models of open economies and global trade. See, for example, Dixon et al. (1982); McKibbin and Sachs (1991); Hertel (1997); and Dixon and Rimmer (2002). 
more elastically via imports than are non-traded goods-which depend on home resources - such an influx must raise relative non-traded prices and therefore appreciate the real exchange rate. Conversely, effluxes cause real depreciations.

Not surprisingly then, wider empirical evidence in support of the BalassaSamuelson hypothesis is mixed. Choudhri and Khan (2004), for example, find favourable evidence using a small sample of developing countries that does not include mainland China, Taiwan or Hong Kong. Bergin et al. (2006) find a positive association between price levels and real per capita income that is strong only in large samples of countries. Miyajima (2005) uses a sample of 15 Organisation for Economic Cooperation and Development (OECD) countries between 1970 and 2000 to establish that the hypothesis does not always hold during growth surges, which on numerous occasions were led by productivity growth in non-traded sectors. The East Asian evidence since 1980 also appears mixed. Only Japan showed a rapid real appreciation following the demise of the Bretton Woods system in 1972 and in association with its correspondingly rapid export-led growth. The same pattern is not observed for Korea, Taiwan or for any of the larger Southeast Asian economies. ${ }^{9}$

With failure of the law of one price for tradable goods, factor endowment changes become important. During the past two decades one such force has been China's 'demographic dividend', stemming from the high proportion of workingaged people in the total population. This, according to Cai and Wang (2005), accounted for about one-quarter of per capita GDP growth between 1980 and $2003 .^{10}$ It has played a critical role in keeping wages and hence the real exchange rate low, thereby enabling the rapid expansion of labour-intensive manufactured exports. In the future, however, the ageing of the population and the consequent decline in the labour supply will have the opposite effect, placing upward pressure on real wages and the real exchange rate. ${ }^{11}$ Alternative population policies, such as the relaxation of the One Child Policy, clearly stand to affect economic growth via the labour supply, and therefore to impact on the real exchange rate as well.

\footnotetext{
${ }^{9} \mathrm{Japan}$ is a special case in the East and Southeast Asian experience. It was the first to develop rapidly but its economy, and particularly its services sector, remained far more closed than for its neighbours, and particularly relative to China.

${ }^{10}$ See Bloom and Williamson 1998 for a generic discussion of the demographic dividend in developing countries.

${ }^{11}$ Golley and Tyers 2006 confirm this, finding that the non-working aged dependency ratio could rise to 43 per cent.
} 
Because largely non-traded services are comparatively skill-intensive, the endowment of skilled labour is a also key determinant. Fogel (2006) predicts that investment in human capital has the potential to serve as China's key engine of economic growth for the next two decades, a point that is well recognised by China's leaders (as emphasised in the eleventh Five-Year Plan). He qualifies the impact of enhancing the quality of labour through education on the growth rate of per capita income and shows that increasing secondary and tertiary enrolment ratios has a sizeable impact on the growth of labour productivity and the per capita GDP growth rate. ${ }^{12}$

\section{Modelling the Determinants of China's Real Exchange Rate}

Here we examine quantitatively the relationship between shocks associated with China's economic growth and its real exchange rate. To do this effectively, a numerical model is required that is global in scope and that incorporates the generalisations of the Balassa-Samuelson assumptions discussed above. Recall that these included productivity growth in non-tradable as well as tradable sectors, departures from the law of one price for tradable goods, a more sophisticated representation of the labour market and an open capital account. With these generalisations, almost all shocks to the economy have implications for the real exchange rate.

We use a model that offers these generalisations. Adapted from Tyers and Shi (2007a, 2007b), it is a multi-region, multi-product dynamic simulation model of the world economy. ${ }^{13}$ In the version used, the world is subdivided into 14 regions (Table 2). Industries are aggregated into three sectors: agriculture (including processed foods), industry (mining and manufacturing) and services (including construction) - the latter being little traded in comparison with the other two. Failures of the law of one price are represented by product differentiation, so that consumers substitute imperfectly between products from different regions. As in other dynamic models of the global economy, the principal endogenous component

\footnotetext{
${ }^{12}$ For example, he calculates that if the tertiary enrolment ratio rose from six to 25 in the next 20 years (putting China where the Western European nations were in 1980), the growth rate of labour productivity would rise by 4.4 per cent between 2000 and 2020, and that this would account for more than 60 per cent of the per capita GDP growth target set in 2002. With the tertiary ratio increasing from 12.5 per cent to 19 per cent between 2000 and 2004, if anything, his estimates could be too conservative.

${ }^{13}$ The model has its origins in GTAP-Dynamic, the standard version of which is a derivative of its comparative static progenitor, GTAP (Hertel 1997). Its dynamics are described in Ianchovichina and McDougall (2000).
} 
Table 2. Regional Composition in the Global Model

\begin{tabular}{|c|c|}
\hline Region & Composition of aggregates \\
\hline \multicolumn{2}{|l|}{ Australia } \\
\hline North America & Canada, Mexico, United States \\
\hline Western Europe & $\begin{array}{l}\text { European Union, including Switzerland and } \\
\text { Scandinavia but excluding the Czech Republic, } \\
\text { Hungary and Poland }\end{array}$ \\
\hline Central Europe and the former Soviet Union & $\begin{array}{l}\text { Central Europe includes the Czech Republic, } \\
\text { Hungary and Poland }\end{array}$ \\
\hline \multicolumn{2}{|l|}{ Japan } \\
\hline China & Includes Hong Kong and Taiwan \\
\hline \multicolumn{2}{|l|}{ Indonesia } \\
\hline Other East Asia & $\begin{array}{l}\text { Republic of Korea, Malaysia, the Philippines, } \\
\text { Singapore, Thailand and Vietnam }\end{array}$ \\
\hline \multicolumn{2}{|l|}{ India } \\
\hline Other South Asia & $\begin{array}{l}\text { Bangladesh, Bhutan, Maldives, Nepal, Pakistan } \\
\text { and Sri Lanka }\end{array}$ \\
\hline South America & $\begin{array}{l}\text { Argentina, Bolivia, Brazil, Chile, Colombia, } \\
\text { Ecuador, Peru, Venezuela, Uruguay }\end{array}$ \\
\hline Middle East and Nth Africa & $\begin{array}{l}\text { Includes Morocco through the Islamic Republic } \\
\text { of Iran }\end{array}$ \\
\hline Sub-Saharan Africa & The rest of Africa \\
\hline Rest of World & $\begin{array}{l}\text { Includes the rest of Central America, the rest of } \\
\text { Indochina, the small Island states of the Pacific, } \\
\text { Atlantic and Indian Oceans and the Mediterra- } \\
\text { nean Sea, Myanmar and Mongolia, New } \\
\text { Zealand and the former Yugoslavia }\end{array}$ \\
\hline
\end{tabular}

Source: The GTAP Global Database, Version 5.

of simulated economic growth is physical capital accumulation. Technical change is introduced in the form of exogenous productivity growth that is sector and factor specific, allowing the analysis of productivity performance that differs between tradable and non-tradable sectors. Consistent with the results indicated in Table 1 for China, baseline productivity in agriculture sectors in most regions grows more rapidly than that in services. This allows continued shedding of labour by agriculture as part of the development process. ${ }^{14}$

\footnotetext{
${ }^{14}$ In the case of China, Wang and Ding (2006) recently estimated that there were 40 million surplus workers in China's agricultural sector. While underemployment is not explicit in our model, the assumption of high labour productivity growth in agriculture implies that agriculture is capable of shedding labour without consequence for its output as workers are drawn away by urban capital accumulation.
} 
Regional capital accounts are open and investors have adaptive expectations about real regional net rates of return on installed capital. In each region, the level of investment is determined by a comparison of expected net rates of return on domestic installed capital with borrowing rates yielded by a global trust, to which each region's saving contributes, adjusted by calibrated region-specific interest premiums. Lagged adjustment processes ensure, however, that financial capital is not fully mobile internationally in the short term, but that the paths of domestic and global interest rates become parallel, separated only by exogenous premiums in the long term. General financial reform is represented by a diminution of the interest premium and this causes an unambiguous influx of financial capital to China.

To augment the model's characterisation of changes in labour supply and quality, it encompasses demographic and economic change. It tracks populations in four age groups, two genders and two skill categories: a total of 16 population groups in each of the 14 regions. The skill subdivision is between production labour (unskilled) and professional labour (skilled). ${ }^{15}$ Each age-gender-skill group is represented as a homogeneous sub-population with a group-specific birth and death rate, labour force participation rate and rates of immigration and emigration. Because the nontraded sector is relatively intensive in skill, trends in skill composition prove to be particularly important. These depend on the rate at which each region's education and social development institutions transform unskilled (production-worker) families into skilled (professional-worker) families. Each year a particular proportion of the population in each production-worker age-gender group is transferred to professional status. The initial values of these proportions depend on the regions' levels of development, the associated capacities of their education systems and the relative sizes of their production and professional labour forces. Rates of transformation change through time in response to corresponding changes in real per capita income and the skilled wage premium. ${ }^{16}$ This skill accumulation process offers the second of the two endogenous sources of growth in all regional economies.

These demographic details help to generalise the model's characterisation of

\footnotetext{
${ }^{15}$ The subdivision between production workers and professionals and para-professionals accords with the International Labour Organisation's occupation-based classification and is consistent with the labour division adopted in the GTAP Database. See Liu et al. (1998).

${ }^{16}$ China's skill share is projected to rise through time while that in its real exchange rate comparator, North America, remains static. The contrast is due to North America's higher initial skill share, its high rate of unskilled immigration and its higher fertility rate.
} 
labour supply and quality in each region. Our analysis shows, however, that while the labour quality changes are strong determinants of the real exchange rate, the underlying labour supply forces are weak (Tyers et al. 2006), at least through a single decade. The one related Balassa-Samuelson generalisation that could prove important is the difference in labour mobility between the rural and industrial sectors on the one hand and the rural and service sectors on the other. In the absence of reliable estimates of the relevant elasticities of labour substitution, this behaviour is omitted from the model. While skill compositions of labour demand differ between sectors according to empirical evidence, unskilled labour is assumed to be homogeneous across sectors and its wage to be the same throughout the economy.

The 16 age-gender-skill groups differ in their shares of regional disposable income, consumption preferences, saving rates and labour force participation behaviour. While the consumption-savings choice differs for each group, it is dependent for all on group-specific real per capita disposable income and the regional real lending rate. Governments are assumed to balance their budgets while saving and borrowing are undertaken by the private sector. The baseline scenario is a 'business-as-usual' projection of the global economy until 2030.

Our focus is on how shocks that enhance the rate of GDP growth impact on the real exchange rate, mirroring shocks examined by Tyers et al. (2006). The real exchange rate of interest is the bilateral rate between China (including Hong Kong and Taiwan) and North America (including Canada and Mexico), since this best parallels China's nominal exchange rate policy and the renminbi valuation debate. It is measured as in Equation (1), except that, since we use a real model, the regional GDP prices are both expressed relative to a common global numeraire. The most significant determinants of this bilateral real exchange rate are once-and-for-all productivity increases, skill transformation rate increases, interest premium decreases (increases in net financial inflows) and tariff decreases (increases in openness or in the import penetration ratio). In each case, we run a new simulation in which the determinant in question is shocked once and for all, as of 2005. We then extract the elasticity of China's real exchange rate to each shock, tracking the values through time to 2030. The results are summarised in Figure 4.

\section{A. Productivity Growth Increase}

We first shock total factor productivity separately in each sector. The elasticity is the percentage departure of the projected real exchange rate or growth rate for each percentage per annum increase in total factor productivity. The overall rate of 
Figure 4. Elasticities of the Projected Real Exchange Rate to Its Key Determinants ${ }^{\mathrm{ab}}$

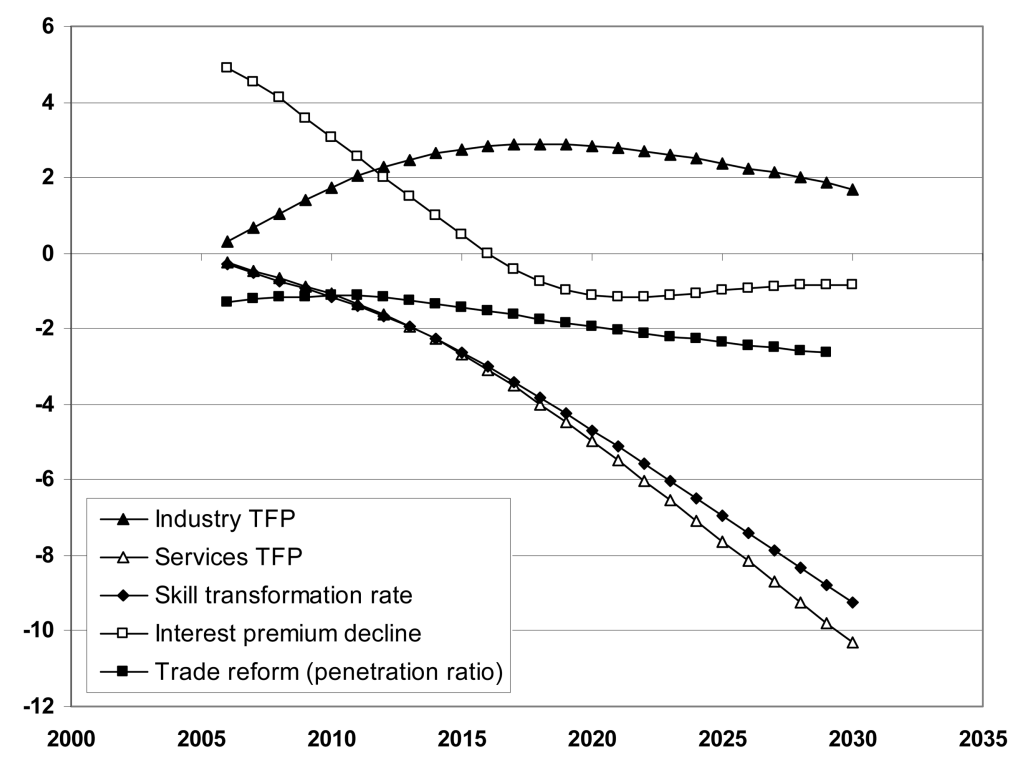

a: This is the percentage departure of the projected real exchange rate for each percentage increase in the overall import penetration ratio, $M / C$, caused by tariff reductions that began in 2005 .

b: The elasticities of the real exchange rate to each determinant are defined as the $\%$ change in the real exchange rate due to the following once and for all changes as of 2005:: Industry and services TFP: $\%$ point change in the annual growth rate of total factor productivity, Skill acquisition rate: \% point change in the proportion of the low-skill labour force that is transformed to high skill in each year, Interest premium decline: $\%$ point decline in the home interest rate due to premium decline, Trade liberalisation: \% decline in the import penetra- tion ratio, which changes year to year but which is due to the liberalisation of all trade distortions remaining after WTO accession reforms over 2005-2010. Source: Simulations using the model described in the text.

economic growth proves to be quite sensitive to such productivity shocks since the larger these are for a particular region, the larger is that region's marginal product of capital. The region therefore enjoys higher levels of investment and hence a double boost to its growth rate. Because 'industry' is by far the greatest contributor to China's trade its productivity is more significant for the real exchange rate than 'agriculture'. The appreciating effects of tradable productivity increases are consistent with the Balassa-Samuelson hypothesis and are, as expected, due to wage growth and relative service price inflation. They are bolstered in the short term by increased investment and hence greater net inflows on the capital account. In the long term, however, the enlargement of the industrial capital stock reduces costs and hence offsets the real exchange rate gains. Also, as expected from the dominance of non-traded sector prices in Equation (2), faster service productivity 
growth depreciates the real exchange rate-modestly in the early years but to a dominant extent in the long term, when it is reinforced by associated capital accumulation.

\section{B. Skill Acquisition Rate Increase}

When the skill acquisition rate is increased in developing regions such as China, where the unskilled (or production) worker population is larger than its skilled (or professional) counterpart, the proportional boost to skilled workers is larger than the proportional loss of unskilled workers. The result is greater output and, other things being equal, a real depreciation. This tendency is enhanced by the fact that the services sector is comparatively skill intensive, so that the shock causes a relatively large boost to service output and hence a relatively large fall in the home service price (relative to North America). The result is a strong responsiveness of GDP growth to skill acquisition and a relatively large real depreciation in the long run. The elasticities in this case are percentage departures of the real exchange rate for each per cent of the production-worker (unskilled) population that is transformed each year. Defined this way, skill transformation places downward pressure on the real exchange rate of a magnitude similar to total factor productivity in services.

\section{Increased Financial Capital Inflow (Interest Premium or Saving Rate Decline)}

In the short term, the decline in China's interest premium results in net capital inflows, which raises investment and therefore increases aggregate demand and the real exchange rate. A positive demand-driven effect is therefore expected in the first instance. In the long term, however, when the effect of the investment on the capital stock is realised, the supply side dominates. More abundant and hence cheaper capital reduces production costs, yielding a real depreciation. The elasticityto-premium decline is large and positive in the short term, with the lag to the switch in sign measuring at least 15 years. A corresponding effect is generated by shifting China's consumption relations so as to reduce its average saving rate. ${ }^{17}$ This results in a surge in financial inflow and a real appreciation in the short run. This appreciation fades through time as financial capital markets adjust and more

\footnotetext{
${ }^{17}$ In each region the model has 16 age-gender-skill groups each of which has endogenous saving, driven by real disposable income and the real interest rate. Each group consumption equation has a regionwide shifter that can be modified to accord with observed total savings changes or shocked by a small proportion to derive an elasticity of sensitivity.
} 
of China's investment is eventually financed from abroad. The associated elasticity has smaller magnitude than that for the interest premium and so it is not shown in Figure $4 .^{18}$

\section{Trade Liberalisation (Increased Openness)}

Trade liberalisation switches demand away from home-produced goods and services towards imported varieties. For a single region, the supply of goods and services from the much larger foreign market is more elastic than that of home varieties, constrained as they are by local factor supplies and technology. The effect of the demand switch, then, is to reduce the relative prices of the home varieties and hence to depreciate the real exchange rate. The elasticity of openness is constructed by dividing the percentage change in the real exchange rate by the percentage point change in the import penetration ratio (the ratio of the value of imports to the total value of domestic consumption). The shock on which it is based is a phased removal of all China's merchandise trade barriers over five years. ${ }^{19}$ The elasticity, also shown in Figure 4, has the expected negative sign, and its magnitude grows through time.

The rise in the elasticity's (negative) magnitude through time occurs because, even though the industries most affected by trade liberalisation are capital intensive, the broad group "industry" in the model is benefited overall, raising the return on physical capital and attracting additional investment. This apparent anomaly occurs because the "industry" aggregate produces goods that are differentiated from competing imports with the degree of differentiation limiting the extent of demand switching. At the same time this industry group is a large importer of intermediate inputs that are also industrial products. It turns out that the gains to the sector from cheaper intermediates outweigh the losses from import competition in final demand. ${ }^{20}$ The effects on GDP are positive, with the raised investment and capital growth tending to reduce costs further and hence to enlarge

\footnotetext{
${ }^{18}$ Defined as the $\%$ change in the real exchange rate for each $\%$ point change in the average saving rate, it takes a value of about 0.4 in the short run. While this seems comparatively small, changes in China's average saving rate have been proportionally larger than our calibrated changes in its investment interest premium.

${ }^{19}$ The elasticity is insensitive to the scale of the liberalisation though not to the composition of China's protection. For the levels of protection embodied in the database for 1997, see Dimaranan and McDougall (2002).

${ }^{20}$ This effect is discussed in detail in Rees and Tyers (2004).
} 
the negative elasticity through time.

\section{Resolution}

There is no doubt that the Balassa-Samuelson appreciating force of Section 2 has been in action in China. Our generalisations of their hypothesis allow consideration of countervailing forces, however, and it is these that must have prevented any significant real appreciation between the early 1990s and 2006. Services productivity and skill acquisition, which are both depreciating because they hold down relative service prices, are shown in the previous section to be potentially strong, yet the evidence of Section 2 suggests relative service prices have risen and therefore that these forces have not been dominant. Other strong forces with potential influence are trade reforms and financial flows on the balance of payments (changes in China's investment interest premium and its average saving rate).

In the short to medium run reductions in the investment premium and average saving rate both raise net financial inflows and so both are strongly appreciating. From Figure 5, however, it is evident that, since the mid-1990s there has in fact been an expansion in net outflows on these accounts, and so the effect has been to apply downward pressure on China's real exchange rate. To see this, note that the equality of net flows on the capital account to the investment-saving gap follows from the standard aggregate expenditure and disposal identities. ${ }^{21}$ Defining net inflows as positive, the "capital account" surplus can be written as:

$$
K A=S_{N F}-\Delta R=I-S_{D}
$$

where $I$ is investment, $S_{N F}$ (net foreign saving) is net private inflow on the financial account and $\Delta R$ is the annual addition to official foreign reserves. In the presence of capital controls, $S_{N F}$ is roughly equal to inward FDI. Both sides of the equation are negative in the case of China, indicating net outflows. Extraordinarily, even though investment accounts for 45 per cent of China's GDP, more than half of its GDP is saved. And it is clear from Figure 5 that, since 1997, the average saving rate has risen substantially faster than investment as a share of

\footnotetext{
${ }^{21}$ The right hand side of this identity stems from the combination of aggregate expenditure on GDP, $Y=C+I+G+X+M$; the fact that GNP is $Y_{N}=Y+N$, where $N$ is net factor income from abroad; the GNP disposal identity, $Y_{N}=C+T+S$, and the balance of payments, $B o P=0=K A+C A$, where the current account is $C A=X-M+\mathrm{N}$.
} 
Figure 5. China's Investment-saving and External Balances (percentage of GDP) ${ }^{\mathrm{a}}$

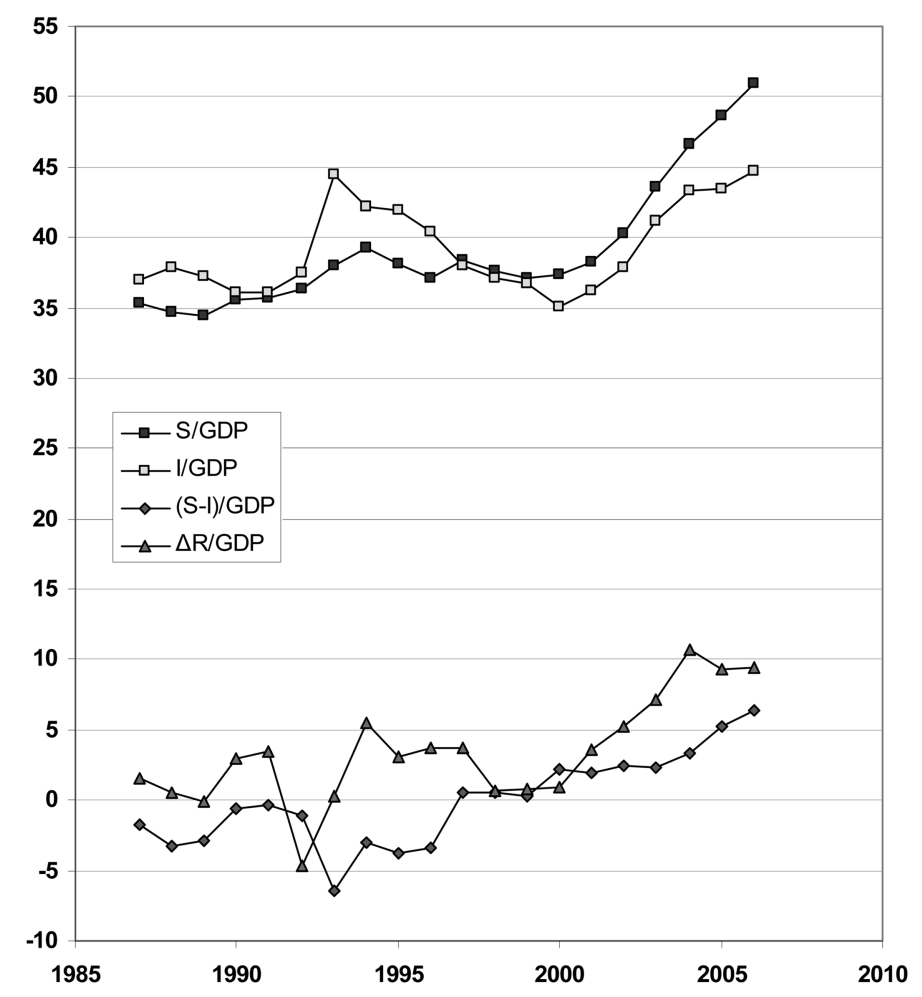

a: Since errors and omissions are large, we have adjusted the least accurately measured items in each sub-account (usually net factor income and net private flows on the financial account) to ensure balance.

Sources: International Monetary Fund (IMF), 2007a. International Financial Statistics, April, International Monetary Fund, Washington, DC. International Monetary Fund (IMF), 2007b. World Economic Outlook Database, April, International Monetary Fund, Washington, DC. Some 2006 figures are derived from data from the Chinese National Bureau of Statistics, 2007. Economist Intelligence Unit, Chinese National Bureau of Statistics.

GDP. While growth in the resulting net financial outflow is likely to have supplied a strong depreciating force, the other candidates may also have been important. The recent surge in overall income growth and urbanisation has seen an acceleration of skill acquisition and a boost to the service economy. At the same time, the lead-up to China's WTO accession saw a substantial reduction in trade distortions.

To separate the effects of each of these forces on the real exchange rate we begin with the baseline model simulation over the decade 1997-2006. This simulation incorporates all measured changes in sectoral productivity, skill acquisition and 
trade liberalisation, as well as saving rates and investment interest premia. The skill acquisition rates are calibrated using the model from wage and sectoral employment data, as described in Tyers and Bain (2006), baseline shocks to saving rates are also calibrated from national accounts data ${ }^{22}$ and the investment premia are calibrated, as indicated in the previous section, from the known path of Chinese investment. ${ }^{23}$ Finally, the trade reform shocks associated with the WTO accession are from Rees and Tyers (2004: Table 3).

The actual and simulated paths of the bilateral real exchange rate between China (incorporating Taiwan and Hong Kong) and North America (incorporating the US, Canada and Mexico) are illustrated in Figure 6. Note, first, that these paths differ from that of the bilateral real exchange rate between mainland China and the US shown in Figure 2. The real exchange rate depreciates further with these aggregations because Hong Kong and Taiwan experienced larger real depreciations against the US in this period and Canada and Mexico both experienced real appreciations against the US. The simulated real depreciation falls slightly short of that recorded, yet, as the figure shows, the model does reproduce the shape of the observed real depreciation through $2006 .^{24}$

The independent effect of each of the forces on the bilateral real exchange rate between China and North America is then discerned by making a number of additional model simulations over 1997-2006. The first is a "no forces" simulation, in which changes to all of the key forces determining the bilateral real exchange rate are removed. Saving rates are shifted to ensure that the ratios of total investment to total saving in China and North America are held constant, restraining the expansion in net outflows on China's capital account and net inflows on North America's; productivity growth rates in all sectors are set at North American levels throughout; no trade policy reforms occur; and skill acquisition rates are shifted to ensure that labour forces and skill shares grow in both regions at the North American rates for the period. Then this no-forces simulation is augmented by each of the individual forces separately, to evaluate their independent effects. The results

\footnotetext{
${ }^{22}$ Consumption equation shifters are here adjusted through time to ensure that total saving accords with the known path of the current account deficit.

${ }^{23}$ Here the model is used to constructing a separate simulation in which known investment is exogenous and the premia are endogenous.

${ }^{24}$ The acceptable performance of the model indicated in Figure 2 extends beyond the recorded real exchange rate. Similar performance is observed for the value of China's bilateral current account surplus with the US, the overall surplus and the volumes of imports and exports.
} 
Figure 6. Actual and Simulated Real Exchange Rates between China and North America ${ }^{a}$

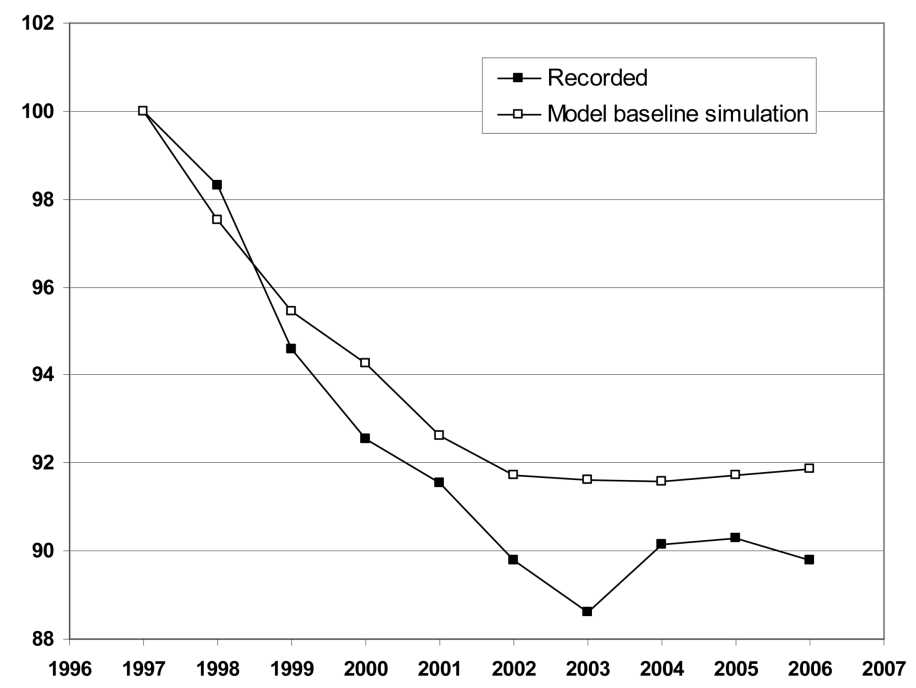

a: Indexed departures from 1997, where China includes Taiwan and Hong Kong and North America includes Canada and Mexico. The recorded series represents indices of $e_{R}=P_{Y} / P_{Y}^{N A m}$, where $P_{Y}$ is the China regional GDP price and $P_{Y}^{N A m}$ is the corresponding North American average GDP price, both evaluated in US\$ as the quotients of nominal and real regional GDP.

Source: IMF, International Financial Statistics (2007) and, for Taiwan, from Central Bank of the Republic of China (Taiwan) http://www.cbc.gov.tw/foreign/fx/minfo 07 4.asp; GDP Deflator; from Directorate-General of Budget, Accounting and Statistics, Executive Yuan, R.O.C. (Taiwan); http:// www.dgbas.gov.tw/public/data/dgbas03/bs4/nis93/np31.xls.

are illustrated in Figure 7.

Higher Chinese productivity growth offers the expected appreciating force, consistent with the results illustrated in Figure 5. Also consistent with those results is that net financial outflows on China's balance of payments and inflows on the North American balance of payments (their current account 'imbalances') both tend to depreciate the Chinese real exchange rate. Similarly, skill acquisition and trade reform offer the expected depreciating forces. In combination, the current account imbalances in both China and North America contribute a depreciation of more than five per cent by 2006. Skill acquisition is a small force in the short run, consistent with the elasticities in Figure 4. Surprisingly significant, however, is the depreciating effect of WTO accession trade reforms, which contribute more than four per cent to the overall real depreciation. In the end, the balance of payments imbalances prove to be, in combination, the most important depreciating forces during 1997-2006. 
Figure 7. Scale of Real Exchange Rate Forces, China vs. North America ${ }^{\mathrm{a}}$

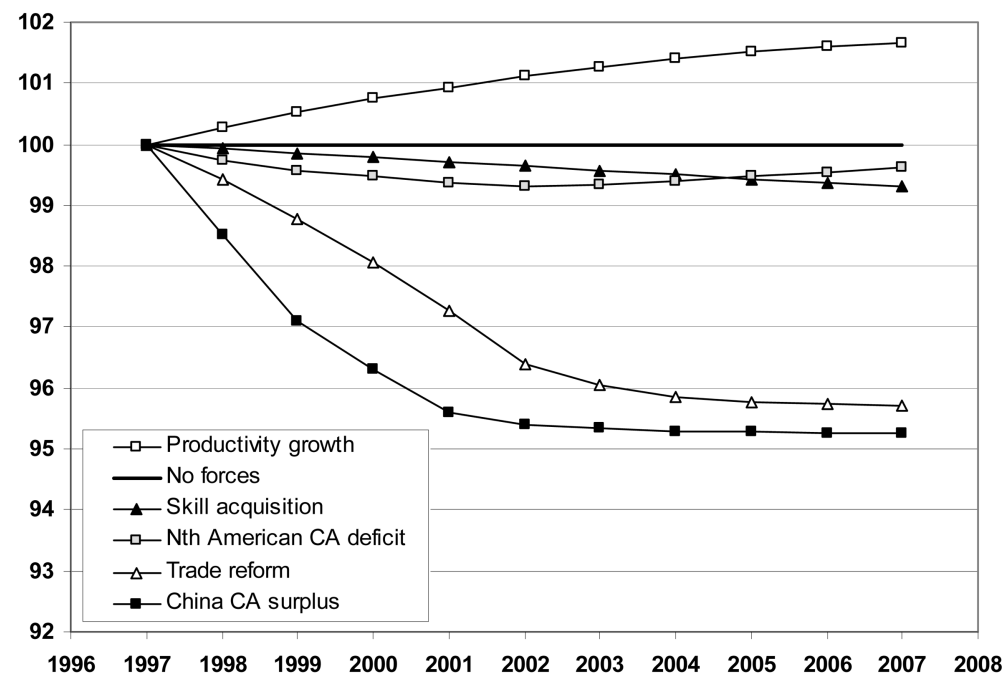

a: Indexed departures from 1997, where China includes Taiwan and Hong Kong and North America includes Canada and Mexico.

Source: Model decomposition simulations described in the text.

\section{Implications for China's Macroeconomic Policy and the Renminbi}

The exchange rate reforms launched by the Chinese authorities in July 2005 were intended to at least demonstrate a departure from the de facto fixed US dollar peg, nominally allowing the currency to fluctuate by up to 0.3 per cent a day. This band was subsequently expanded, yielding a cumulative bilateral appreciation of 10 per cent by the end of 2007 (Figure 3). It is a widely held view, however, that the upward movement of the RMB is restricted by China's exchange rate policy and by the associated accumulation of official foreign reserves (Lardy 2006:85). Indeed, the reserve accumulation is seen as a discretionary policy choice designed to prevent appreciation and to maintain strong export growth, a practice referred to as 'monetary mercantilism'. ${ }^{25}$

In our view this is unfair criticism, at least in the case of China. The two critical factors in its macroeconomic behaviour are its high saving rate and its capital controls. If these are taken as exogenous, at least in the short run, the low underlying real

\footnotetext{
${ }^{25}$ The works mounting the monetary mercantilist position are reviewed by Aizenman and Lee (2006), who conclude in the end that China's substantial reserves are more likely to be precautionary.
} 
Table 3. The Balance Sheet of the People's Bank of China, ca. 2006

\begin{tabular}{ll}
\hline \multicolumn{1}{c}{ Assets } & \multicolumn{1}{c}{ Liabilities } \\
\hline $\begin{array}{l}\text { Domestic credit, DC } \\
\text { Central bank claims on depository and other financial } \\
\text { corporations and on the central government }\end{array}$ & The monetary base, $M_{B}$ \\
20 per cent GDP & Currency and bank reserves \\
& 37 per cent GDP \\
& Sterilisation bonds, $\boldsymbol{S B}$ \\
Official foreign reserves, $R$ & Debt to the Chinese public \\
41 per cent GDP & 14 per cent GDP \\
& Other liabilities, OL \\
& Includes government ownership \\
\hline
\end{tabular}

Source: People's Bank of China, 2006. Balance Sheet of Monetary Authority, People's Bank of China, Beijing.

exchange rate is due to the surplus of saving over investment, as our modelling indicates, and the reserve accumulation is a non-discretionary consequence of the capital controls. To see this, consider a rearrangement of Equation (4): $\Delta R=S_{D}-I+S_{N F}$. This indicates that, as long as total domestic saving exceeds investment and capital controls prevent the matching of inward FDI by private outflows, $\Delta R$ must be positive. The PBC has accumulated these reserves, and sterilised their monetary consequences via the sale of its own bonds. Once imports are financed, at least de jure, capital controls leave no private demand for foreign exchange. Chinese commercial banks therefore relinquish the surplus to the PBC which then must place it abroad.

The broad structure of the PBC's balance sheet is indicated in Table 3. Just as the reserves have come to dominate the asset side of the balance sheet, sterilisation bonds have assumed significance on the debit side. In effect, the PBC has acted as a conduit for domestic savers who might otherwise acquire foreign assets but are restricted from doing so by capital controls. The current pressure from abroad to revalue therefore places the $\mathrm{PBC}$ in a difficult position for two reasons. First, since the assets of the PBC are primarily in US dollars and its liabilities are in renminbi, too prompt an appreciation of the renminbi would result in substantial losses that would need to be covered in renminbi from the government budget. ${ }^{26}$ Second, and more important, if the path of the underlying real exchange rate is flat (as in Figure 2), then from Equation (1), any decision by the PBC to revalue would require further monetary tightening and a reduction in the inflation rate, with the attendant

\footnotetext{
${ }^{26}$ This concern has very recently been addressed via the exchange between the government and the PBC of a large quantity of domestic bonds in return for foreign bonds, the latter to be maintained by the government as the assets of a state-run Foreign Exchange Investment Company.
} 
risk of a return to the growth-sapping deflation of the late 1990s. ${ }^{27}$

All this presages two essential questions: why are the capital controls retained and why is China's saving rate so high? The capital controls imply a lack of faith in China's commercial banks to behave prudentially in foreign exchange markets and a fear on the part of the government of a repeat of the Asian financial crisis of 1997. Hitherto, China's banking system has lacked derivative markets for currency and debt instruments to do the necessary hedging and it is not sufficiently distant from decades of soft budget constraints associated with the channelling of government subsidies to state-owned enterprises through accumulated debt. As these controls are relaxed it is likely that an increasing share of the financial outflow on China's balance of payments will be private, as portfolios are adjusted to more closely resemble those in other middle income and developed economies (Tyers and Bain 2007).

Turning to the saving rate, Chinese private households save about a third of their disposable incomes (Azziz and Cui 2007). This is high by international standards but not extraordinary for Asia. It stems from intertemporal choices by private households that are driven by changes in the provision of health, education and retirement benefits as more of the population transitions from rural or government employment to the urban private sector. The key to the very high proportion of GDP that is saved is an extraordinary level of corporate saving, which is associated on the one hand with enormous profits made by some monopoly state owned enterprises and the failure of the central government to extract dividends from its ownership of these firms and, on the other, with those firms' disposal of profits internally or in the form of cash holdings. These factors are largely structural and amenable in the longer term to on-going financial and competition reforms. In the near term, however, they are unlikely to be influenced by monetary policy and the exchange regime.

\section{Conclusion}

The Balassa-Samuelson hypothesis is borne out for China, in that productivity

\footnotetext{
${ }^{27}$ Approaching the end of 2007 there was a rise in the inflation rate from around 3 per cent to above 6 per cent per year. This acceleration was due to an underlying real appreciation which was caused, in turn, by a surge in private inflows on the capital account against China's capital controls as the interest rate spread between China and the US widened. The PBC allowed quicker nominal appreciation in this period, however, as Figure 3 shows, thereby controlling the inflation, consistent with equation (1). The cause of this episode was the US mortgage crisis and the response of the US central bank. Its effect on China's real exchange rate is therefore likely to be temporary, unlike the forces considered here.
} 
has apparently grown faster in China's tradable sector than in those of its trading partners and faster than in its own or foreign non-tradable sectors. Accordingly, there has been relative service price inflation. The flat trajectory of its real exchange rate is therefore a puzzle, the resolution of which requires the generalisation of the hypothesis to incorporate failures of the law of one price for tradable goods and a more sophisticated representation of the labour market. This opens the way for depreciating forces that have been offsetting the Balassa-Samuelson effect, including China's high saving rate, which has caused net financial outflows on the balance of payments, trade and other microeconomic reforms and the rising labour force share of skilled workers.

To examine these forces, a dynamic model of the global economy is used to construct a baseline business-as-usual simulation to 2030. The principal determinants of China's economic growth are then shocked separately and their independent effects on the real exchange rate observed over time. In the short term, the key determinants are the saving rate and the investment interest premium, which determine financial flows on the balance of payments. Financial capital influx appreciates the real exchange rate and efflux depreciates it. In the medium term, scope does emerge for Balassa-Samuelson real appreciation, if services lag sufficiently behind industrial productivity. In the long term, however, if services remain relatively skill intensive on average, their performance is bolstered by both direct productivity improvements and skill acquisition, and the result is a substantial depreciating force.

The model is then used to decompose the flat trajectory of the real exchange rate 1997-2006. The results suggest that the strongest of these forces is the rise of China's total savings relative to its investment and the associated expansion of net outflows on its capital account, with a significant contribution from WTO accession trade reforms. While much attention is paid in the literature to the undervaluation of the renminbi, blaming this on China's monetary policy and, in particular on the PBC's accumulation of foreign exchange reserves, in our view misses the critical point that the PBC's monetary policy is necessitated by financial immaturity. In particular, while China's savings exceed its investment, the reserves and capital controls merely alter the public-private composition of external flows but need not significantly affect their magnitudes.

In the long term, since Chinese productivity growth has been higher than that of its trading partners for more than a decade, and considerable scope remains for productivity catch-up in services, the latter could bear down on the real exchange 
rate. It is difficult to ignore the fact that the majority of the growth-related shocks examined-including overall (and particularly services) productivity growth, professional training and further trade reform-all cause the real exchange rate to depreciate in the long term. Yet, whichever productivity pattern dominates, the future path of the real exchange rate will also depend heavily on financial flows and hence on China's domestic savings relative to its investment. Eventually, its saving rate must fall. When it does, net flows on the capital account will be reversed, resulting in a strong appreciating force. The long-term outcome will then depend on the extent to which this force is offset by continued skill acquisition and services productivity growth.

\section{Acknowledgements}

Funding for the research described in this paper is from Australian Research Council Discovery Grant No. DP0557889. Thanks are due to Bu Yongxiang, Huang Yiping and Chris Milner for useful discussions on the topic, to Christopher Kent and participants in an April 2007 Reserve Bank of Australia seminar for valuable comments, to Elena Ianchovichina for useful comments following presentation at the 10th Annual Conference on Global Economic Analysis, Purdue University, to Terrie Walmsley for technical assistance with the GTAP Database, to Wang Xiaolu for help with China's national accounts and to Iain Bain for research assistance. The authors are also indebted to two anonymous reviewers who offered insightful and constructive comments on an earlier draft.

Received 30 June 2007, Revised 7 March 2008, Accepted 8 April 2008

\section{References}

Aizenman, J. and Lee, J., 2006. Financial versus Monetary Mercantilism: Long Run View of Large International Reserves Hoarding, Working Paper WP/06/280, International Monetary Fund, Washington, DC.

Amiti, M. and C. Freund, 2007. "An Anatomy of China's Export Growth", paper presented at the conference on Global Implications of China's Trade, Investment and Growth, International Monetary Fund, Washington DC, 6 April.

Azziz, J. and L. Cui, 2007. "Explaining China's Low Consumption: the Neglected Role of Household Income", International Monetary Fund Working Paper WP 07/181, Washington DC. 
Balassa, B., 1964. 'The Purchasing Power Parity Doctrine: a Reappraisal', Journal of Political Economy, 72(6), 584-96.

Bergin, P.R., Glick, R. and Taylor, A.M., 2006. 'Productivity, Tradability and the Long Run Price Puzzle', Journal of Monetary Economics, 53(8), 2,041-66.

Bloom, D.E. and Williamson, J.G., 1998. 'Demographic Transitions and Economic Miracles in Emerging Asia', World Bank Economic Review, 12(3), 419-55.

Cai, F. and Wang, D., 2005. 'Demographic Transition: Implications for Growth', in R. Garnaut and L. Song (eds), The China Boom and its Discontents, Asia Pacific Press, The Australian National University, Canberra.

2006. 'Employment Growth, Labour Scarcity and the Nature of China's Trade Expansion', in R. Garnaut and L. Song (eds), The Turning Point in China's Economic Development, Asia Pacific Press, The Australian National University, Canberra.

Callan, E., 2007. 'Clinton and Obama back China Crackdown", Financial Times 5 July (www.FT.com).

Chang, J. and Tyers, R., 2003. 'Trade Reform, Macroeconomic Policy and Sectoral Labour Movement in China', in R. Garnaut and L. Song (eds), China 2003: new engine for growth, Asia Pacific Press, The Australian National University, Canberra.

Choudhri, E.U. and Khan, M.S., 2004. Real Exchange Rates in Developing Countries: Are Balassa-Samuelson Effects Present?, Working Paper, No.WP/04/188, International Monetary Fund, Washington, DC.

Coudert, V. and Couharde, C., 2005. Real Equilibrium Exchange Rate in China, Working Paper, No.2005-01, CEPII, Paris.

Crucini, M.J., Telmer, C.I. and Zachariadis, M., 2005. 'Understanding European Real Exchange Rates', American Economic Review, 95(3), 724-38.

Dimaranan, B.V. and McDougall, R.A., 2002. Global Trade, Assistance and Production: the GTAP 5 Data Base, May, Center for Global Trade Analysis, Purdue University, Lafayette.

Dixon, P.B., Parmenter, B.R., Sutton, J. and Vincent, D.P., 1982. ORANI, a Multi-Sectoral Model of the Australian Economy, North Holland, Amsterdam.

Dixon, P.B. and Rimmer, M.T., 2002. Dynamic General Equilibrium Modelling for Forecasting and Policy: a Practical Guide and Documentation of Monash, North Holland, Amsterdam.

Drine, I. and C. Rault, 2005. 'Can the Balassa-Samuelson Theory Explain Long Run Real Exchange Rate Movements in OECD Countries?', Applied Financial Economics, 15(8), 519-30.

Fan, G., 2006. 'Global Imbalance, China and the International Currency System', in R. Garnaut and L. Song (eds), The Turning Point in China's Economic Development, Asia Pacific Press, The Australian National University, Canberra.

Fogel, R., 2006. Why is China likely to Achieve its Growth Objectives?, Working Paper W12122, National Bureau of Economic Research, Cambridge, Mass.

Frankel, J., 2004. On the Renminbi: the Choice between Adjustment under a Fixed Exchange Rate and Adjustment under a Flexible Rate, Working Paper 11274, 
National Bureau of Economic Research, Cambridge, Mass.

Golley, J. and Tyers, R., 2006. 'China's Growth to 2030: Demographic Change and the Labour Supply Constraint', in R. Garnaut and L. Song (eds), The Turning Point in China's Economic Development, Asia Pacific Press, Canberra; version in Chinese forthcoming in Chinese Labor Economics.

Goldstein, M., 2004. Adjusting China's Foreign Exchange Rate, Revised version of a paper delivered at the International Monetary Fund's seminar on China's Foreign Exchange Rate System, Dalian, China, 26-27 May. Available from www.iie.com (accessed September 2006).

Hertel, T.W. (ed.), 1997. Global Trade Analysis Using the GTAP Model, Cambridge University Press, New York.

Holtz, C.A. (2006), "New Capital Estimates for China”, China Economic Review 17, 142-185.

Ianchovichina, E. and McDougall, R., 2000. Theoretical Structure of Dynamic GTAP, GTAP Technical Paper, No.17, Purdue University, Lafayette.

International Monetary Fund (IMF), 2007a. International Financial Statistics, April, International Monetary Fund, Washington, DC.

2007b. World Economic Outlook Database, April, International Monetary Fund, Washington, DC.

Lardy, N., 2006. 'China's Interaction with the Global Economy', in R. Garnaut and L. Song (eds), The Turning Point in China's Economic Development, Asia Pacific Press, The Australian National University, Canberra.

Liu, J., Van Leeuwen, N., Vo, T.T., Tyers, R. and Hertel, T.W., 1998. Disaggregating Labor Payments by Skill Level in GTAP, Technical Paper, No. 11, September, Center for Global Trade Analysis, Department of Agricultural Economics, Purdue University, Lafayette.

Lu, F., 2006. China's Productivity Growth, an International Comparison, China Center for Economic Research Working Paper C200604, April, Peking University, Beijing, (in Chinese).

Ma, Y., 2006. A Comparative Study of the Competitiveness of the Domestic and Foreigninvested Service Industries in China, Centre for Public Policy Studies Working Paper, No. 176, Lingnan University, Hong Kong, December; presented at the ACE International Conference, APEC Studies Centre, City University of Hong Kong, 18-20 December 2006.

McKibbin, W.J. and Sachs, J., 1991. Global Linkages: Macroeconomic Independence and Cooperation in the World Economy, Brookings Institution.

Miyajima, K., 2005. Real Exchange Rates in Growing Economies: How Strong is the Role of the Nontradables Sector, Working Paper 05/233, International Monetary Fund, Washington, DC.

National Bureau of Statistics (China), 2007. China Statistical Abstract 2006., China Statistics Press.

People's Bank of China, 2006. Balance Sheet of Monetary Authority, People's Bank of China, Beijing.

Prasad, E., Rumbaugh, T. and Wang, Q., 2005. Putting the Cart before the Horse: Capital 
Account Liberalization and the Exchange Rate in China, Policy Discussion Paper 05/ 01, International Monetary Fund, Washington, DC.

Rees, L. and R. Tyers (2004), "Trade Reform in the Short Run: China's WTO Accession", Journal of Asian Economics 15(1), 1-31, January-February.

Samuelson, P., 1964. 'Theoretical Notes on Trade Problems', Review of Economics and Statistics, 46(2), 145-54.

Tyers, R. and I. Bain, 2006. "The Global Economic Implications of Freer Skilled Migration", Working Papers in Economics and Econometrics No 468, Australian National University, Canberra, June, Revised July 2007.

,2007. "Appreciating the Renminbi", Working Papers in Trade and Development No.2007/09, Division of Economics, Research School of Pacific and Asian Studies, Australian National University, Canberra, August.

Tyers, R. and Q. Shi, 2007a. 'Global Demographic Change, Policy Responses and their Economic Implications', The World Economy, 30(4), 537-66.

2007b. Global Demographic Change, Labour Force Growth and Economic Performance, Working Papers in Economics and Econometrics, No. 462, The Australian National University, Canberra.

Tyers, R., Y. Bu and I. Bain, 2008. "China's Equilibrium Real Exchange Rate: a CounterFactual Analysis", Pacific Economic Review, 13(1), 17-39, March. Earlier version in Chinese: Economic Research Journal, June 2001, 21-32.

Tyers, R., Golley, J., Bu, Y. and Bain, I., 2008. China's Economic Growth and its Real Exchange Rate, China Economic Journal, 1(2), 123-145, July.

Wang, J. and Ding, S., 2006. 'A Re-estimation of China's Agricultural Surplus Labour-the Demonstration and Modification of Three Prevalent Methods', Frontiers of Economics in China, 1(2), 171-81.

Wang, T., 2004. 'Exchange Rate Dynamics', in E. Prasad (ed.), China's Growth and Integration into the World Economy: Prospects and Challenges, International Monetary Fund Occasional Paper 232, Washington, DC.

Woo, W.T. (2006), "China's Macroeconomic Imbalances: the Liquidity Tango Mechanism", in J.J. Teunissen and A. Akkerman (eds.), Global Imbalances and the US Debt Problem: Should Developing Countries Support the US Dollar? Volume 1, Forum on Debt and Development, The Hague, The Netherlands. and G. Xiao (2007), "Facing Protectionism Generated by Trade Disputes: China's Post-WTO Blues", Chapter 4 in R. Garnaut and L. Song (eds.), China: Linking Markets for Growth, Canberra: Asia Pacific Press and Social Sciences Academic Press (China), July: 45-70. 